\title{
Preface: Hegel in Russia
}

\author{
Ilya Kliger · David Bakhurst
}

Published online: 7 March 2014

(C) Springer Science+Business Media Dordrecht 2014

The shadow cast by Hegel and Hegelian thought over Russian culture during much of the last two centuries is vast, and much scholarly work has been dedicated to describing it. The articles collected in this special issue extend the earlier scholarship in a number of different directions, exploring the effects of migrating Hegelianism on a wide range of intellectual domains and cultural practices: history of ideas, poetics of everyday behavior, the fashioning of the self in history, mutations of narrative form, aesthetics, historiographic imaginaries of the modern, literary criticism, and more. ${ }^{1}$

The issue opens with three articles on early Russian Hegelianism. Victoria Frede examines the highly influential reception of Hegelian thought by Nikolaj Stankevič through the prism of translation, analyzing his little known rendering of an article by the Hegelian philosopher Joseph Willm. Frede lays bare the conservative and theistic dimensions of the early reception of Hegel, soon to be swallowed up by the Russian version of left-Hegelianism of the 1840s. Vadim Shkolnikov focuses on the other major figure in the history of Russian Hegelianism, Vissarion Belinskij. In Shkolnikov's account, Belinskij discovers himself in the paradoxical position of a

\footnotetext{
1 The articles appearing in this volume are based on papers presented at a conference on "Hegel to Russia and Back," which took place in April 2013 at New York University. The editors would like to express their gratitude to NYU's Jordan Center for the Advanced Study of Russia, NYU's Humanities Initiative and CUNY Graduate Center's Center for the Humanities for financial support. Special thanks to Yanni Kotsonis and Fiona Neale-May of the Jordan Center and to Katherine Carl of the CUNY Center for the Humanities for their generous help with organizing the event. The editors would also like to thank the Jordan Center for financial support in preparing this issue.
}

I. Kliger $(\bowtie)$

Russian and Slavic Studies, NYU, 19 University Place, Room 206, New York, NY 10012, USA

e-mail: ik32@nyu.edu

D. Bakhurst

Department of Philosophy, Queen's University, Kingston, ON K7L 3N6, Canada

e-mail: david.bakhurst@queensu.ca 
full-fledged historical self-consciousness living in a "non-historical" nation and attempts to resolve this dilemma by turning to the work of Pushkin. Ilya Kliger's article discusses the reception of Hegel's political philosophy within the "social imaginary" of early Russian realism to highlight some of the specificities of the Russian novelistic tradition vis-à-vis its Western-European counterpart.

The articles dealing with early Russian Hegelianism are followed by three discussions of turn-of-the-century and post-Revolutionary appropriations. Jeff Love takes up questions that have haunted twentieth-century discussions of Hegelabsolute knowledge, the end of history and finitude — as they emerge in the work of Nikolaj Fjodorov, Vladimir Solov'ëv, and Alexandre Kojève. At stake is the stark choice, in the Russian "modernist" reception of Hegel, between ironic finitude and radical transhumanism, the latter expressed in the "philosophical madness" of the quest for divinization. Nikolaj Plotnikov's article studies the contribution of GAKhN (the State Academy for the Study of the Arts), and in particular of Gustav Špet, to the reception of Hegelian aesthetics in the 1920s. Hegel helped the GAKhN theorists evade the pitfalls of both idealist and Marxist aesthetics, and the category of recognition (Anerkennung) emerges as crucial for this task. The subject of Inessa Medzhibovskaya's article, Anatoly Lunačarskij, displays a similar interest in Hegel's aesthetics and philosophy of history, woven into a lifelong engagement with Goethe's art and thought. For Lunačarskij, Hegel proves invaluable for posing the question of the place of individual creation, whether political or aesthetic, within the grand, cataclysmic narrative of History.

Concluding this collection are three articles that focus on Stalinist and postStalinist Hegelianisms. Siarhei Biareishyk takes up Kojève's Hegelian problematic of the end of history and tests the applicability of this notion, and the temporality implied by it, to the institution of the five-year plan. The five-year plan, in turn, prompts a non-teleological reading of Hegel, in the spirit of some recent French interpretations, those of Pierre Macherey and Catherine Malabou. Vadim Shneyder focuses on Georg Lukács's work on realism from the 1930s, arguing that Hegelian aesthetics figures prominently within it. In particular, Lukács's more Hegelian writings of the 1930s depart from the better-known Theory of the novel in effecting a conceptual rapprochement between the genres of the epic and the novel, a development that contributes to a conceptualization of Socialist-Realist prose as well as a re-reading, in light of that practice, of its nineteenth-century novelistic forebears. Finally, David Bakhurst's article traces the career of one of the most formidable twentieth-century Marxist Hegelian philosophers, Evald Il'enkov. Il'enkov's committed Hegelianism played an indispensible part in his struggle for sophisticated philosophical Marxism against doctrinal orthodoxy, and, at several points in his career, got him into trouble with the academic and political establishment. Bakhurst finds parallels between Il'enkov's predicament and that of Nikolaj Bukharin, working on the Philosophical arabesques while incarcerated in the Lubjanka Prison, and argues that Hegel's influence is crucial to the manner in which they responded to their respective situations, which both ended in tragedy.

We hope that the articles gathered in this collection show that the far-reaching nature of Russian engagement with Hegel's philosophy during the nineteenth and twentieth centuries provides us with especially rich material for continuing to pose 
the central Hegelian question of the relationship between the rational and the actual, while at the same time foregrounding the mechanisms, or perhaps we should say, the dialectics and creativity of trans-cultural understanding. 